\title{
ANALISIS KEPUASAN DALAM PELAYANAN UNTUK MENINGKATKAN PENJUALAN TOKO MAJU KIMIA TANGERANG
}

\author{
Niera Feblidiyanti \\ Dosen Fakultas Teknik Prodi Teknik Industri Universitas Pamulang \\ dosen02275@unpam.ac.id
}

\begin{abstract}
ABSTRAK
Analisis Kepuasan Dalam Pelayanan Untuk Meningkatkan Penjualan (pada Toko Maju Kimia). Adapun tujuannya, Untuk mengetahui kepuasan dalam pelayanan konsumen Toko Maju Kimia saat ini, serta untuk menganalisis kepuasan dalam pelayanan konsumen untuk meningkatkan penjualan pada Toko Maju Kimia. Penelitian dilakukan menggunakan metoda deskriptif kualitatif, dengan menggunakan teknik fokus grup diskusi yang dilakukan dengan mengumpulkan semua responden dan melakukan diskusi tentang permasalahan yang diteliti, dengan sampel sebanyak 5 responden.Fakta kepuasan pada Toko Maju Kimia saat ini boleh dikatakan masih dibatas standar untuk salah satu jenis usaha jual beli mungkin disebabkan oleh masih banyaknya konsumen yang kurang loyal dan masih sedikit kurang singkron, karena permintaan konsumen yang beragam dan kurang tanggapnya memberikan informasi untuk kebutuhan konsumen, Gab Antara Sintesa \& Fakta kepuasan konsumen di toko, yaitu masih sedikit kurang singkron karena permintaan konsumen yang beragam dan kurang tanggapnya memberikan informasi untuk kebutuhan konsumen. Jika keinginan dan harapan pelanggan terpenubi maka kepuasan akan tercapai dengan sendirinya. Dalam melakukan penelitian ini digunakan matrikx IE, IFE, EFE, SWOT dan SPACE, Dengan demikian, analisis kepuasan dalam pelayanan untuk meningkatkan penjualan pada Toko Maju Kimia manggunakan strategi intensif, yang mana dilakukan dengan pengembangan produk, pengembangan pasar, penetrasi pasar, dilihat kondisi spesifik.
\end{abstract}

Kata Kunci: Kepuasan, Pelayanan, Strategi Penjualan, , Matriks EFE, SWOT,

\section{PENDAHULUAN}

Di dalam dunia usaha terlebih yang bergerak dibidang ritel untuk meningkatkan keuntungan membutuhkan berbagai cara memasarkan produnya. Sehingga peranan manajemen dalam menentukan stategi dan langkah untuk mempertahankan dan meningkatkan usaha toko dalam mencapai keuntungan yang maksimal sangatlah pentingKarena banyak perusahaan yang berfokus pada kepuasaan konsumen, sangat peting sekali diperhatikan agar produknya tidak ditinggalkan oleh konsumen.

Untuk mncapai tujuan perusahaan yang ingin mendapatkan keuntungan dan pengembangan usaha yang maksimal dalam menyikapi persaingan usaha sejenis diperlukan strategi bersaing yang tepat dalam pelayanan khususnya. sehingga business opportunity dalam penjualan bahan kimia dapat diraih. Hal ini disebabkan pelayanan merupakan urat nadi toko, dalam arti sangat kritis kedudukannya dalam menentukan keberlangsungan usaha. Selain itu untuk merebut pangsa pasar diperlukan usaha memasarkan produk yang baik agar penjualan dan laba perusahaan tidak berkurang.

Dengan menjalanakan aktivitas pemasaran langsung yang mana penjualan langsung berhubungan dengan konsumen maka, menawarkan produk, harga waktu dan tempat yang tepat adalah kunci keberhasilan usaha retail. 
Untuk memahami secara baik bisnis retail, manajemen dan strategi pengembangannya pelaku usaha membutuhkan penerapan fungsi manajemen secara keseluruhan baik fungsi keuangan, sumber daya manusia, operasional dan pemasaran produk dan jasa dalam pemenuhan kebutuhan konsumen.

Jika di teliti lebih lanjut lagi bisnis retail tidaklah semudah yag dibayangkan karena banyaknya usaha serupa, lokasi, dominasi merk dan modal yang terbatas juga merupakan faktor penentu. Jadi sebaiknya sebelum memulai usaha retail sebaiknya dipastikan terlebih dahulu apakah sudah siap bersaing dalam bisnis ini atau belum.

Menurut Bermans dan Evans, 1992 yang menjadi penghubung perusahaan manufakur atau produsen terhadap pedagag besar dan konsumen pemakai adalah fugsi dari perusahaan retail. Jadi barang dan jasa yang dikonsumsi konsumen merupakan berkat pendistribusian dari perusahan retail yang tidak hanya membantu konsumen tapi juga bagian dari penting ekonomi negara.

Toko Maju Kimia bergerak dibidang penjualan bahan kimia (retail) berupa bahanbahan kimia dan olahannya yang berada di Tangerang. Setelah melakukan diskusi dengan pemilik Toko Maju Kimia dijelaskan bahwa toko mengalami penurunan penjualan karena kurangnya strategi dalam persaingan khususnya promosi. Melihat beberapa factor ini toko Maju Kimia harus segera mengambil langkah agar tidak terkikis dengan toko sejenis, dengan memperbaiki kualitas dalam hal pelayanan konsumen. Dengan demikian toko Maju Kimia tahu apa yang menjadi harapan dan keinginan konsumen selama ini dan bagaimana penilaian mereka terhadap pelayan yang telah dilakukan toko.

Karena Gab Antara Sintesa \& Fakta Penjualan di toko Maju Kimia hanya menggunakan strategi word-of-mouth yang seyogyanya kurang efektif dalam promosi dan memperkenalkan toko ke dunia luar.

Oleh karena latar belakang tersebut, toko perlu menyusun/ melakukan fokus untuk kepuasan dan pelayanan konsumen maka tesis ini berusaha untuk mendapatkan cara untuk meningkatkan penjualan produk bahan kimia di Toko Maju Kimia dan mampu menjadi toko bahan kimia yang dikenal dan disukai oleh konsumennya, maka tesis ini akan berjudul
"Analisis Kepuasan dalam Pelayanan untuk Meningkatkan Penjualan di Toko Maju Kimia".

\section{DASAR TEORI}

\section{A. Manajemen.}

Menurut Mulayu S.P. Hasibuan (2002:2), manajemen merupakan pemanfaatan sumber daya manusia dan sumber lainya untuk mencapai tujuan secara efektif dan efesien.

Menururt Richard L. Daft (2002:8), "manajemen merupakan pencapaian sasaransasaran organisasi melalui perencanaan pengorganisasian, kepemimpinan, dan pengendalian sumber daya organisasi dengan efektif dan efesien.

Definisi lain berdasarakan Sondang P. Siagian dalam Ferdiansyah (2014:18) menyebutkan manajemen merupakan tujuan memperoreh suatu hasil melaui kemampuan dan keterampilan melalui kegiatan-kegiatan orang lain.

Dari beberapa penjelasan diatas maka kita dapat mengartikan manajemen merupakan ilmu yang digunakan dalam suatu organisasi secara efektif dan efesien untuk mencapai suatu tujuan dan sasarannya.

\section{B. Pemasaran}

Ilmu pemasaran sangat penting di kehidupan zaman modern ini. Dari zaman ke zaman pemasaran merupakan sarana yang terus dikembangkan oleh manusia. Pemasaran memiliki peranan penting dalam dunia usaha karena pemasaran adalah inti dan ujungtombak dalam proses terealisasikannya keinginan perusahaan. Dapat dikatakan pencapaian tujuan bisnis terletak pada cara mengkombinasikan fungsi-fungsi meliputi bidang pemasaran, keuangan, produksi dan bidang lainya.

Jadi pada dasarnya pemasaran bertujuan memenuhi keinginan, kepuasan konsumen dan mencapai sasaran dalam suatu organisasi melalui kegiatan mendistribusikan barang dan jasa. Dalam konsep dan tujuan perusahaan faham betul faktor penting untuk mencapai sukses adalah pemasaran. Sehingga pengkoordinasian dan pengelolaan harus dilakukan dengan baik agar keuntungan yang diinginkan perusahaan dapat terealisasi, sehingga kebutuhan konsumen dapat terpenuhi dengan baik dengan kata lain konsumen orientasi. 
Penegasan Konsep pemasaran juga disampaikan oleh Kotler dan Keller (2009:19), perusahaan harus efektif dalam Menyerahkan, menciptakan dan mengkounikasikan nilai dan kebutuhan konsumen pada pasar dan sasaran. Selain itu konsep pemasaran juga menitik beratkan pada kepuasan konsumen agar konsumen tidak berpaling ke pesaing agar tujuan meningkatkan penjualan dapat terealisasi dengan baik.

\section{Kepuasan Pelanggan}

Kekecewaan pelanggan atas produk maupun jasa harus ditindak lanjuti dengan serius karena dalam memenuhi kepuasan konsumen bukan hanya dari segi produk, pelayanan dan harga yang bersaig saja. Dan untuk melihat semua itu perusahaan harus terlibat langsung untuk memenuhi tujuan tersebut.

Untuk menilai kepuasan konsumen harus dilihat dari:

1. Survey kepuasan konsumen

2. Menganalisis konsumen yang sudah tidak kembali.

3. Mencoba atau menyewa ghost shopping

4. Mendengarkan keluhan dan saran. Selain itu juga ada beberapa faktor yang menjadi penentu kepuasan konsumen:

a. Biaya

b. Harga

c. Kualitas pelayanan

d. Kualitas produk

e. Brand atau merk

\section{III.METODE DAN TEKNIK PENGUKURAN}

\section{A. Metode Penelitian}

Analisis kualitatif adalah metoda yang dipilih untuk melakukan penelitian ini selanjutnya diperdalam dengan analisis deskriptif. Pada penelitian ini peneliti merupakan kunci dan generalisasi merupakan penekanan untuk penelitian kualitatif ini. Sedangkan analisis deskriptif di pergunakan untuk mengetahui gambaran dan kondisi obyek yang diteliti, sehingga bisa dilakukan analisis yang lebih tepat guna mendapatkan jawaban dari permasalahan yang ada. Analisis kualitatif dilakukan untuk mengkaji dan menetapkan strategi apa yang harus dipilih sehingga terjadi perbaikan dari pencapaian sebelumnya

\section{B. Waktu dan Tempat penelitian.}

1. Penelitian pada Toko Maju Kimia di

Kampung Curug Kulon Kecamatan Curug, Kabupaten Tangerang, Banten

2. Penelitian ini dilakukan selama kurang lebih 5 bulan.

\section{Jenis Dan Sumber Data}

\section{Jenis Data}

Jenis data yang digunakan dalam penelitian ini meliputi observasi, wawancara, dan dokumen pendukung lainya. Dari data tersebut maka dalam penelitian ini akan dianalisa adalah data yang bersifat kualitatif baik berupa angka maupun fakta/informasi yang hanya dapat dianalisa dengan teknik analisa kualitatif. Data yang diperoleh di dapat dari data primer dan sekuder.

\section{Sumber data}

a) Data Primer

Data primer merupakan pengumpulan langsung data oleh peneliti untuk mendapatkan informasi (fakta \& data) secara untuk memecahkan masalah atau untuk memenuhi tujuan penelitian lainnya. Data primer yang di dapat dalam penelitian ini dari wawancara mendalam yang terstruktur terhadap perusahaan pro toko bahan kimia dan observasi langsung terhadap pengembangan pasar.

Target responden meliputi:

1)Pemilik Toko

2)Pelayan Toko

3)Kasir Toko

4)Pelanggan

5)Peneliti sendiri

b)Data Sekunder

Data sekunder juga merupakan sumber data yang penting bagi penelitian ini selain data primer, data sekunder adalah sumber data yang penting bagi penelitian. Data sekunder ini adalah sumber informasi penting lainnya yang bersifat sebagai data pendukung penelitian untuk memperkaya informasi dan fakta penelititan. Data ini bisa diperoleh dari data publikasi beberapa instansi terkait yaitu data dinas perindustrian, dinas pertanian, laporan penelitian terdahulu, journal, sumber pustaka lain yang sesuai dengan topik penelitian ini.

\section{IV.HASIL DAN PEMBAHASAN}


A. Hasil dan Pembahasan.

\section{Analisis Matriks Internal Factor Evaluation (IFE)}

Analisis lingkungan iternal toko menghasilkan empat kkuatan dan empat kelemahan. Matriks IFE disusun berdasarkan identifikasi kekuatan dan kelemahan yang dimiliki Toko, dimana key succes factor dari lingkungan internal yang dirangkum dalam sebuah tabel Internal Factor Evaluation (IFE). Bobot (weight) dan peringkat (rating) atas factor - faktor analisiss internal diperoleh berdasarkan kuesioner yang diberikan kepada responden. Kemudian dari hasil pembobotan dan peringkat tersebut dilakukan perhitungan untuk menentukan rata - ratanya. Adapun hasil perhitungan dari matriks IFE dapat:

Table matrix IFE

\section{Analisis Matriks External Factor Evaluation (EFE)}

Berdasarkan hasil analisis lingkungan eksternal terdapat empat peluang dan empat ancaman yang dihadapi toko. Matriks EFE disusun berdasarkan identifikasi peluang dan ancaman yang dihadapi toko:

Table matrix EFE

\begin{tabular}{|c|c|c|c|c|}
\hline \multirow{2}{*}{$\begin{array}{l}\mathbf{N} \\
\mathbf{0}\end{array}$} & $\begin{array}{l}\text { Faktor Analisis } \\
\text { Eksternal }\end{array}$ & \multirow{2}{*}{$\begin{array}{c}\text { Bob } \\
\text { ot }\end{array}$} & \multirow{2}{*}{$\begin{array}{c}\text { Rati } \\
\text { ng }\end{array}$} & \multirow{2}{*}{ Skor } \\
\hline & $\begin{array}{c}\text { PELUANG } \\
\text { (Opportunity) }\end{array}$ & & & \\
\hline 1 & $\begin{array}{l}\text { Meningkatnya daya beli } \\
\text { masyarakat }\end{array}$ & 0.35 & 4 & 1.50 \\
\hline 2 & $\begin{array}{l}\text { Kemungkinan menguasai } \\
\text { pasar }\end{array}$ & 0.15 & 4 & 0.60 \\
\hline 3 & $\begin{array}{l}\text { Peminat bahan kimia } \\
\text { semakin meningkat }\end{array}$ & 0.25 & 4 & 1.00 \\
\hline 4 & $\begin{array}{l}\text { Tersedianya variasi/olahan } \\
\text { produk jadi }\end{array}$ & 0.25 & 3 & 0.75 \\
\hline & Sub Total O & 1.00 & & 3.85 \\
\hline & ANCAMAN (Threat) & & & \\
\hline 1 & Munculnya usaha sejenis & -0.30 & 3 & $\begin{array}{c}- \\
0.90\end{array}$ \\
\hline 2 & $\begin{array}{l}\text { Peningkatan peraturan } \\
\text { pemerintah }\end{array}$ & -0.20 & 2 & $\begin{array}{c}- \\
0.40\end{array}$ \\
\hline 3 & $\begin{array}{l}\text { Konsumen sensitif } \\
\text { terhadap harga }\end{array}$ & -0.25 & 1 & $\overline{-}-\overline{25}$ \\
\hline 4 & $\begin{array}{l}\text { Kondisi ekonomi dalam } \\
\text { negeri }\end{array}$ & -0.25 & 2 & $\begin{array}{c}- \\
0.50\end{array}$ \\
\hline & Sub Total T & 1.00 & & 2.05 \\
\hline
\end{tabular}

Sumber: Hasil Pengolahan Data 2017

\section{Matriks Posisi Analisis dan Evaluasi Tindakan SPACE}

Selanjutnya perusahaan untuk memperkuat Analisa menggunaka Matriks Space utnuk melihat perkembangan dan posisi toko Maju Kimia.

Matriks Space ini tergantung pada jenis variable dan organisasi yang dipakai untuk dimensi yang ada. Selain factor yang ada factor IFE dn EFE juga menjadi pertimbangan dalam Matriks.

a. Posisi Analisis Internal antara lain:

1)Kekuatan keuangan/financial strength (FS) meliputi:

a) Laporan keuangan.

b) Keuntungan perusahaan

Apakah perusahaan sudah mencapai target keuntungan yang diharapkan.

c) Tingkat ekonomi

d)Perbandingan laba bersih dan biaya (ROI)

e) Perbandingan laba bersih dengan asset toko pada akhir periode (ROA)
2) Stabilitas
Lingkungan/Environmental

Stability (ES) meliputi:

a) Harga pesaing

Harga yang ditetapkan oleh pesaing dengan produk yang sama. Apakah lebih murah atau lebih mahal.

b)Analisis pemasaran pesaing

Analisis pemasaran produk pesaing apakah lebih baik atau tidak, dibanding produk kita.

c) Daya beli masyarakat

Kemampuan beli masyarakat terhadap produk yang ditawarkan.

d) Gaya beli masyarakat

Suatu kesenangan masyarakat dalam membeli produk.

b. Posisi Analisis eksternal antara lain:

1) Keunggulan Kompetitif /Competitif Advantage (CA) meliputi:

a) Kualitas produk

Produk berkualitas adalah produk yang layak buat masyarakat.

b) Inovasi produk

Inovasi produk merupakan penemuan produk baru yang berbeda dar produk yang ada.

c) Inovasi kebijakan perusahaan

Perubahan kebijakan perusahaan untuk meningkatkan kesejahteraan dalam pemasaran produk ataupun karyawan.

d) Loyalitas konsumen Kesetiaan konsuemen untuk suatu produk, baik barang maupun jasa tertentu.

e) Pangsa pasar (market share)

Berupa hasil pencapaian toko terhadap pesaing yang dilihat dari perkembangan karyawan. 
2)Kekuatan Industri/ Industri Strange

(IS) meliputi:

a) Potensial pertumbuhan

Potensi pertumbuhan toko sekarang dan yang akan datang.

b)Kemampuan teknologi

Kemampuan teknologi yang dimiliki toko harus bias bersaing dengan pesaing.

c) Produktivitas

Bagaimana toko maju kimia manfaatkan sumber daya yang ada dengan baik.

d)Intensitas kapital

Ukuran sistem ekonomi yang dikendalikan untuk mendapatkan keuntungan yang sebesar besarnya.

e) Ketersediaan sumber daya

Banyaknya ketersediaan bahan baku untuk produk berkualitas

Vektor arah Toko Maju Kimia berlokasi di kuadran Konservatif (kiri atas) Matriks SPACE, dimana Toko Maju Kimia ada pada posisi lebih baik menggunakan kekuatan internalnya untuk memanfaatkan peluang eksternal, mengatasi kelemahan internal, dan menghindari ancaman eksternal.

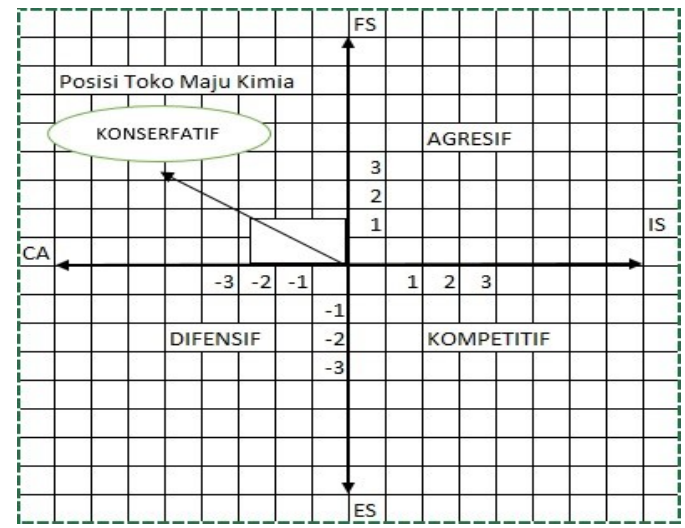

Hasil Matriks SPACE

\section{Matriks SWOT}

Matriks SWOT digunakan untuk menetapkan atau menentukan analisis kepuasan dalam pelayanan konsumen di Toko Maju Kimia berdasarkan kekuatan, kelemahan, peluang dan ancaman. Sebelum perumusan analisis kepuasan dalam pelayanan konsumen dimasukan dalam analisis SWOT.

\section{Matriks SWOT}




\section{d. Analisis WT}

Agar kelemah dan ancaman yang di hadapi toko Maju Kimia tidak menghambat kemajuan toko, maka peningkatan kualitas, jenis bahan kimia, kompetensi karyawan, dan melakukan penetrasi pasar merupakan langkah utama yang harus di jalankan supaya kelemahan dan ancaman itu juga menjadi kekuatan demi peningkatan penjualan toko Maju Kimia.

Dari hasil analisa SWOT dapat ditentukan 2 analisis kepuasan dalam pelayanan untuk Toko Maju Kimia antara lain:

1)Analisis kepuasan dalam pelayanan, analisis ini terapkan dan di implementasikan oleh Toko Maju Kimia dengan cara:

1. Meningkatkan promosi iklan

2. Meningkatkan SDM

2)Analisis penetrasi pasar di terapkan oleh Toko Maju Kimia dengan berbagai cara seperti:

1. Meningkatkan pelayanan

2. Meningkatkan kualitas produk

3. Meningkatkan kualitas karyawan

4. Mempromosikan cara baru untuk menggunakan produk

\section{V.KESIMPULAN}

Berdasarkan penelitian yang telah dilakukan dapat ditarik kesimpulan:

1. Analisis kepuasan dalam pelayanan konsumen di Toko Mau Kimia saat ini boleh dikatakan masih jauh dibawah standar karena pelayan toko hanya melayani apa yang dibutuhkan konsumen saja dan hal ini menyebabkan pelanggan tidak loyal pada toko.

2. Analisi kepuasan pelayan dalam meningkatkan pejualan di Toko Maju Kimia dapat dilakukan dengan cara sebagai berikut:

a. Meningkatkan promosi iklan dan SDM

b. Analisis penetrasi pasar

Penetrasi pasar ini dapat diimplementasikan oleh toko Maju Kimia dengan berbagai cara seperti:

a. Meningkatkan pelayanan

b. Meningkatkan kualitas produk c. Mempromosikan cara baru untuk menggunakan produk

Hal ini dikuatkan lagi dengan hasil analisa matriks Space, maka analisis kepuasan dalam pelayanan untuk meningkatkan penjualan pada Toko Maju Kimia manggunakan strategi intensif.

\section{DAFTAR PUSTAKA}

Alma, Buchari. 2005. Manajemen Pemasaran dan Pemasaran Jasa. Bandung: CV Alfabeta.

David, F. 2009. Manajemen Strategi: KonsepKonsep (Buku I. Edisi 12). Jakarta (ID): PT Indeks Kelompok Media.

Depdikbud. 1990. Kamus Besar Bahasa Indonesia. Jakarta: Balai Pustaka.

Dharmayanti, Diah. 2006. Analisis Dampak Kinerja Layanan dan Kepuasan Sebagai Variabel Moderating Terhadap Loyalitas Nasabah. Jurnal Manajemen Pemasaran.

Fredy Rangkuti. 2003. Mengukur Kepuasan Pelanggan. PT. Elex Media Computindo

Keegan, Waren J. 2001. Manajemen Pemasaran Global. Edisi ke-6. Jakarta: FE-UI

Kotler, Philip. 1997. Manajemen Pemasaran, Analisis Pemasaran dan Pengendalian. Jilid 2 Edisi ke-8. Jakarta: Erlangga.

Kotler, Philip. 2002. Manajemen Pemasaran. Jilid 2. Alih Bahasa oleh Hendra Teguh dkk. Edisi Milenium. Jakarta: PT

Prenhallindo.Kotler, Philip dan Amstrong. 2007. -Dasar Pemasaran. Edisi ke-9. Cetakan ke-2. Jakarta: PT Indeks

Tumanggor, Rusmin, dkk. 2013. Buku Panduan Penulisan Tesis. Edisi VI. Pamulang: Universitas Pamulang. 